\title{
SOLVING THE PROBLEMS OF DAYLIGHTING AND TRADITION CONTINUITY IN A RECONSTRUCTED VERNACULAR BUILDING
}

\author{
Eglè ŠIOŽINYTĖ, Jurgita ANTUCHEVIČIENE் \\ Department of Construction Technology and Management, Vilnius Gediminas Technical University, \\ Sauletekio al. 11, 10223 Vilnius, Lithuania
}

Received 27 Jun 2013; accepted 19 Jul 2013

\begin{abstract}
Seeking for saving traditional forms, sizes, proportions and other features of vernacular architecture and satisfying norms for a contemporary building sometimes is not an easy task. The presented case study about indoor daylighting in Lithuanian vernacular architecture shows the existing problem. The authors of the article suggest possible variants of how to improve daylighting in vernacular buildings. The aim of the conducted research is to propose a rational solution to the problem using multiple criteria assessment. Alternative variants can be characterized by a number of quantitative and qualitative criteria. Thus, for ranking alternatives and achieving the most rational solution, the use of the Analytic Hierarchy Process (AHP) to evaluate the relative importance of criteria as well as the application of Multiple Criteria Decision Making (MCDM) methods are put forward. The case study presents possible alternatives for improving daylighting in the reconstructed building and simultaneously analyses the process of saving the features of vernacular architecture applying the AHP for weighting criteria and Complex Proportional Assessment (COPRAS), Technique for Order Preference by Similarity to Ideal Solution (TOPSIS) and Weighted Aggregated Sum Product Assessment (WASPAS) for ranking alternative solutions. It is estimated that the utility degree of the best ranked alternative exceeds the further ranked alternatives from 29 to 49 percent.
\end{abstract}

Keywords: vernacular building; vernacular architecture; daylighting; windows; MCDM, COPRAS; TOPSIS; WASPAS; AHP.

Reference to this paper should be made as follows: Šiožinytė, E.; Antuchevičienė, J. 2013. Solving the problems of daylighting and tradition continuity in a reconstructed vernacular building, Journal of Civil Engineering and Management 19(6): 873-882. http://dx.doi.org/10.3846/13923730.2013.851113

\section{Introduction}

Vernacular architecture should be fully integrated into the modern life of the community in such a way as to retain local practices and ways of life (Battaini-Dragoni 2008). When talking about the development of this architecture, the question remains of how new developments based on traditional features should look like, which features should remain and which may be forgotten. Necessarily, we lose something old when creating something new, but professional innovations always give more for socium than consuming (Bučas, Mlinkauskienè 2011). It is curious to see what architecture will tell to the future generations and what innovative architectural solutions are deemed to be acceptable when working with new designs based on vernacular architecture features or while reconstructing the old ones. New layers should represent the ideas, technology, materials and architectural language of each generation (Macdonald 2011). There are a number of principles that, if followed, can result in successful extensions that will preserve, even enhance, the character of the original building (Oram, Stelfox 2004).

Old vernacular buildings frequently do not satisfy some of the norms for a contemporary building, and in some cases, we can face the problems when trying to find the balance between new requirements/standards and tradition continuity. One of those encountered in vernacular architecture is that minimal daylighting parameters determined in building regulations are not always satisfied. It is also not entirely clear how to find the balance between new requirements/standards/other norms and old traditions when solving the daylighting problem.

The issue mentioned above is detected in Lithuanian vernacular architecture. Vernacular architecture is officially and legally propagated in the protected areas of the country. In the rest part of the country there is no directional promotion of this type of architecture. Moreover, regulations on the protected areas, e.g. requirements for architecture, and other building regulations intersect when talking about indoor daylighting (Reglamentation of Protection of Aukštaitija Region National Park 2002; STR 2.02.01:2004). In some cases, it is possible to observe the situation when satisfying both regulations is impossible. Then, the question of how to solve the problem in the right way arises.

Using Multiple Criteria Decision Making (MCDM) methods assists in finding rational decisions on various problems. These methods are applied in different research 
fields, and one of those presents MCDM methods applied for building design, construction and development (Šaparauskas et al. 2011; Ogunkah, Yang 2012; Mela et al. 2012; Akadiri et al. 2013; Kuzman et al. 2013; Tamošaitienè et al. 2013; Zavadskas et al. 2013a). Also, some researches apply MCDM methods for rural buildings and their development (Zavadskas, Antucheviciene 2007; Jeong et al. 2012, 2013; Hashemkhani Zolfani, Zavadskas 2013).

Looking for the balance between contemporary norms and tradition continuity, it is important to evaluate various criteria, such as the importance of tradition continuity, the use of modern constructions, materials and techniques, sustainability, health and comfort, aesthetics, etc. Different researchers analyse the above introduced aspects of vernacular architecture on an individual basis (van Hoof, van Dijken 2008; Foruzanmehr, Vellinga 2011; Keizikas et al. 2012; Yüksek, Esin 2013). The novelty of the current research is a suggestion to use the multiple criteria approach and analyse several aspects simultaneously.

The article seeks for actualizing one of the problems of developing Lithuanian vernacular architecture associated with indoor daylighting. Also, the aim of this paper is to present possible ways of improving indoor daylighting for vernacular architecture when trying to save the tradition and satisfy minimal daylighting norms determined in building regulations. The problem is evaluated using multiple quantitative and qualitative criteria. The weight of each criterion is calculated using the Analytic Hierarchy Process (AHP) method. Possible solutions are ranked and the best solution identified for the analysed case study using MCDM methods such as Complex Proportional Assessment (COPRAS), Technique for Order Preference by Similarity to Ideal Solution (TOPSIS) and Weighted Aggregated Sum Product Assessment (WASPAS).

\section{Satisfying minimal norms for daylighting in dwellings based on the features of vernacular architecture}

\subsection{Existing situation}

Daylighting parameters (DP) for dwellings can be evaluated determining the ratio of the window glazed surface area in the room and the floor area of the room. STR 2.02.01:2004 regulates minimal daylighting parameters depending on the type of the room (Table 1) that must be observed when designing and constructing new buildings.

Table 1. Minimal daylighting parameters depending on the type of the room (according to STR 2.02.01:2004)

\begin{tabular}{lc}
\hline \multicolumn{1}{c}{$\begin{array}{c}\text { Premises where daylighting } \\
\text { is obligatory }\end{array}$} & $\begin{array}{c}\text { Minimal window glazed } \\
\text { surface and room floor } \\
\text { area ratio required }\end{array}$ \\
\hline $\begin{array}{l}\text { Entrance tambour; stairwell hall; } \\
\text { common use corridors of the house }\end{array}$ & $1: 12$ \\
\hline Living rooms & $1: 6$ \\
\hline Kitchen & $1: 8$ \\
\hline $\begin{array}{l}\text { Living rooms and kitchen daylight- } \\
\text { ed through windows on the inclined } \\
\text { roof plane }\end{array}$ & $1: 10$ \\
\hline
\end{tabular}

The condition of DP satisfaction can be checked by determining minimal required window glazed surface area $A_{W \text { min }}$ and comparing it with the existing window glazed surface area $A_{W}$ in the room:

$$
A_{W} \geq A_{W \min } \text {. }
$$

Minimal required window glazed surface area $A_{W}$ min is evaluated determining the minimal required ratio of the window glazed surface and room floor area. The study is limited only to the analysis of DP for living rooms. According to minimal daylighting requirements, these premises should get the maximum quantity of natural light. The following calculations are based on the ratio of the window glazed surface and the room floor area 1:6 (Table 1):

$$
A_{W \min }=\frac{A_{F}}{6},
$$

where $A_{F}$ - the floor area of the room $\left(\mathrm{m}^{2}\right)$.

The window glazed surface area in room $A_{W}$ is equal to the sum of the glazed surface areas of each window:

$$
A_{W}=A_{W 1}+A_{W 2}+\ldots+A_{W n},
$$

or, if all windows in the room have the same dimensions

$$
A_{W}=A_{W 1} \times n,
$$

where $n$ is the number of windows in the room.

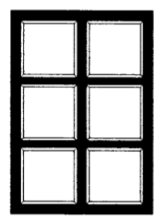

$50: 50$

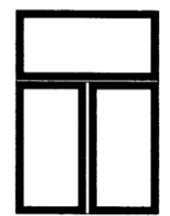

$70: 30$

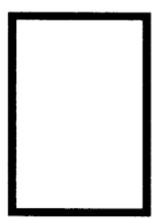

$85: 15$
Fig. 1. Approximate proportions of the glazed surface and frame areas in the window $(0.7 \times 1.0 \mathrm{~m})$

Figure 1 illustrates the change of proportions depending on the window glazed surface and window frame area, when different types of frames exist. For example, on a typical vernacular six-part window, the frame occupies about 50 percent of the total window area; on a three-part window, the frame occupies about 30 percent.

Checking a minimal DP condition for the room is presented in Table 2 where a room in a building of typical vernacular architecture is analysed. The area of the room having 6 windows $(0.7 \times 1.0 \mathrm{~m})$ is $36.00 \mathrm{~m}^{2}$. Four possible variants of windows with different proportions of the window glazed surface area and frame area are taken into consideration.

The differences between the minimal required and existing window glazed surface area for the room are rather significant in all presented cases (Table 2). Also, it should be noted that the condition presented in Eqn (1) is not satisfied in any case. Even at 100 percent of window glazing (dimension of windows makes $0.7 \times 1.0 \mathrm{~m}$ ), it is 
impossible to satisfy minimal DP parameters described in regulations when a defined type of premises is analysed.

The problem is also illustrated by checking how daylighting parameters meet the current regulations in the old vernacular architecture of Lithuania. Five dwellings with different parameters (different window glazed surface area and floor area) characteristic of different Lithuanian ethnographic regions, including Aukštaitija, Dzūkija, Suvalkija (Sūduva), Žemaitija and Mažoji Lietuva (Dubičiai 1989; Kačinskaitè et al. 2008; Šešelgis et al. 1965) were chosen. They are presented as A, B, C, D and E types of building, respectively in Table 3 .

The calculations of this research are assumed that window glazed surface area $A_{W 1}$ is equal to the whole window area, with no taking into account a frame area. Accordingly, the results (Table 3) show the situation disclosing better conditions (with bigger window glazed surface area) than those in reality.

The results in Table 3 indicate that all analysed cases do not satisfy norms required for building regulations. The maximum difference between the minimal required and existing window glazed surface area of the room is about 4 times in B-type dwelling with the room area of $15.36 \mathrm{~m}^{2}$ and with 1 window having the dimensions of $0.7 \times 1.0 \mathrm{~m}$. This means that the window glazed surface area should be enlarged about 4 times. The smallest difference can be attributed to E-type dwelling with the room area of $14.28 \mathrm{~m}^{2}$ and 2 windows with the dimensions of $1.0 \times 1.2 \mathrm{~m}$. This room, with the chosen condition for research, satisfies a minimal DP condition (Eqn (1)); however, it should be noted that calculations are performed in better conditions then they really are, i.e. without taking into account the area of frames. Consequently, the condition is not satisfied.

Living rooms of dwellings should meet at least minimum daylighting requirements to insure the quality of the life of residents. This can be done by increasing the window glazed surface area, which would mean the enlargement of windows or an increase in the quantity of windows. However, in some cases, under the circumstances of a typical building of vernacular architecture, it can be hardly achieved. Then, the question is how the compromise between meeting the current building standards and keeping the continuity of vernacular architecture can be achieved.

Table 2. Difference between the minimal required and existing window glazed surface area of the room

\begin{tabular}{|c|c|c|c|c|c|c|}
\hline $\begin{array}{l}\text { Floor area } \\
\text { of the } \\
\text { room } A_{F}, \\
\quad\left(\mathrm{~m}^{2}\right)\end{array}$ & $\begin{array}{l}\text { Quantity of } \\
\text { windows in } \\
\text { the room } n \text {, } \\
\text { (qty) }\end{array}$ & $\begin{array}{l}\text { Proportions of the win- } \\
\text { dow glazed surface and } \\
\text { frame area when win- } \\
\text { dow measurements are } \\
\quad 0.7 \times 1.0 \mathrm{~m}\end{array}$ & $\begin{array}{l}\text { Window glazed } \\
\text { surface area } A_{w 1} \\
\text { when window } \\
\text { measurements are } \\
0.7 \times 1.0 \mathrm{~m},\left(\mathrm{~m}^{2}\right)\end{array}$ & $\begin{array}{l}\text { Window } \\
\text { glazed surface } \\
\text { area in the } \\
\text { room } A_{W}, \\
\left(\mathrm{~m}^{2}\right)\end{array}$ & $\begin{array}{l}\text { Minimal win- } \\
\text { dow glazed } \\
\text { surface area of } \\
\text { the room } \\
A_{W \min },\left(\mathrm{m}^{2}\right)\end{array}$ & $\begin{array}{l}\text { Difference } \\
\text { between } A_{W} \\
\text { and } A_{W} \text { min } \\
\text { (times) }\end{array}$ \\
\hline \multirow[t]{4}{*}{36.00} & \multirow[t]{4}{*}{8} & $50: 50$ & 0.35 & 2.10 & \multirow[t]{4}{*}{6.00} & 2.86 \\
\hline & & $70: 30$ & 0.49 & 2.94 & & 2.04 \\
\hline & & $85: 15$ & 0.595 & 3.57 & & 1.68 \\
\hline & & $100: 0$ & 0.70 & 4.20 & & 1.43 \\
\hline
\end{tabular}

Table 3. The minimal required and existing window glazed surface area of the room

\begin{tabular}{|c|c|c|c|c|c|c|c|}
\hline $\begin{array}{l}\text { Building } \\
\text { type }\end{array}$ & $\begin{array}{l}\text { Floor area of } \\
\text { the room } A_{F}, \\
\qquad\left(\mathrm{~m}^{2}\right)\end{array}$ & $\begin{array}{l}\text { Quantity of } \\
\text { windows in } \\
\text { the room } n \text {, } \\
\text { (qty) }\end{array}$ & $\begin{array}{l}\text { Sizes of } \\
\text { windows in } \\
\text { the room, } \\
\text { (m) }\end{array}$ & $\begin{array}{l}\text { Window } \\
\text { glazed su- } \\
\text { rface area* } \\
A_{W 1},\left(\mathrm{~m}^{2}\right)\end{array}$ & $\begin{array}{c}\text { Window } \\
\text { glazed surface } \\
\text { area in the } \\
\text { room } A_{W}, \\
\left(\mathrm{~m}^{2}\right)\end{array}$ & $\begin{array}{l}\text { Minimal win- } \\
\text { dow glazed } \\
\text { surface area of } \\
\text { the room } \\
A_{W \text { min }},\left(\mathrm{m}^{2}\right)\end{array}$ & $\begin{array}{c}\text { Difference } \\
\text { between } A_{W} \\
\text { and } A_{W} \text { min } \\
\text { (times) }\end{array}$ \\
\hline \multirow[t]{2}{*}{$\mathrm{A}$} & 35.28 & 5 & \multirow[t]{2}{*}{$0.7 \times 1.0$} & \multirow[t]{2}{*}{0.70} & 3.50 & 5.88 & 1.68 \\
\hline & 35.28 & 4 & & & 2.80 & 5.88 & 2.10 \\
\hline \multirow[t]{2}{*}{ B } & 42.25 & 4 & \multirow[t]{2}{*}{$0.7 \times 1.0$} & \multirow[t]{2}{*}{0.70} & 2.80 & 7.04 & 2.51 \\
\hline & 15.36 & 1 & & & 0.70 & 2.56 & 3.66 \\
\hline \multirow[t]{5}{*}{$\mathrm{C}$} & 40.88 & 5 & \multirow[t]{5}{*}{$0.8 \times 1.0$} & \multirow[t]{5}{*}{0.80} & 4.00 & 6.81 & 1.70 \\
\hline & 31.36 & 3 & & & 2.40 & 5.23 & 2.18 \\
\hline & 14.08 & 2 & & & 1.60 & 2.35 & 1.47 \\
\hline & 10.73 & 1 & & & 0.80 & 1.79 & 2.24 \\
\hline & 9.86 & 1 & & & 0.80 & 1.64 & 2.05 \\
\hline \multirow[t]{5}{*}{$\mathrm{D}$} & 21.60 & 2 & \multirow[t]{5}{*}{$0.7 \times 1.0$} & \multirow[t]{5}{*}{0.70} & 1.40 & 3.60 & 2.57 \\
\hline & 18.90 & 2 & & & 1.40 & 3.15 & 2.25 \\
\hline & 15.40 & 2 & & & 1.40 & 2.57 & 1.83 \\
\hline & 12.74 & 2 & & & 1.40 & 2.12 & 1.52 \\
\hline & 6.76 & 1 & & & 0.70 & 1.13 & 1.61 \\
\hline \multirow[t]{5}{*}{$\mathrm{E}$} & 19.04 & 2 & \multirow[t]{5}{*}{$1.0 \times 1.2$} & \multirow[t]{5}{*}{1.20} & 2.40 & 3.17 & 1.32 \\
\hline & 14.28 & 2 & & & 2.40 & 2.38 & 0.99 \\
\hline & 12.58 & 1 & & & 1.20 & 2.10 & 1.75 \\
\hline & 11.56 & 1 & & & 1.20 & 1.93 & 1.61 \\
\hline & 8.70 & 1 & & & 1.20 & 1.45 & 1.21 \\
\hline
\end{tabular}




\subsection{Possible ways of solving the problem of daylighting}

There could be a few possible variants on solving the problem of daylighting using architectural solutions to the new buildings based on the features of vernacular architecture or reconstructing old vernacular buildings: 1) increasing the size of windows while maintaining typical traditional proportions; 2) increasing the size of windows by changing the proportion of window height and width; 3) increasing the quantity of windows; 4) using new glass structures for building facades, as much as possible trying to maintain the traditional appearance of vernacular architecture; 5) using new glass structures for building facades, more or less changing the traditional appearance of vernacular architecture.

The proportions or dimensions of typical traditional windows are given in literature about Lithuanian vernacular architecture: window width and height proportion $0.7 \times 1.0 \mathrm{~m}$ or $0.8 \times 1.0 \mathrm{~m}$ (Andriušyte et al. 2008 ; Bertašiūte et al. 2009), more specific dimensions $-0.7 \times 1.0 \mathrm{~m}$ and $0.8 \times 1.0 \mathrm{~m}$ (Bertašiūtè et al. 2008; Šešelgis et al. 1965). In some cases, windows can reach the dimensions of $1.0 \times 1.2 \mathrm{~m}$ (Šešelgis et al. 1965). Windows are usually divided into several parts (3-6 or even more parts).

The first from the possible solutions, i.e. increasing the window size while maintaining typical traditional proportions, may not always be perfectly adapted. It is difficult to ensure satisfying the norms required in building regulations and saving traditional features of vernacular architecture at the same time. A window can be proportionally enlarged only up to a certain limit, which, in each case of the building, can be very individual due to the parameters of the whole building. The windows that are bigger than $1.5 \mathrm{~m}$ in height actually become difficult to implement according to the whole building structure. There could be not enough space to put ceiling beams on loadbearing walls. Moreover, the windows could be covered with roof eaves. To avoid these problems, it could be possible to increase the height of the room. However, any increase in dwelling parameters makes changes in the proportions of the whole building or individual parts and therefore in the overall appearance of dwelling.

The other ways to solve daylight problems using architectural solutions to new dwellings based on vernacular architecture, such as increasing the window size by changing the proportion of window height and width or increasing the quantity of windows, also seem to be quite problematic.

Changing proportions is contradictory to the intention of saving traditional forms of vernacular architecture. This means that a new kind of windows can appear.

Increasing the quantity of windows in dwellings is not the best choice, and therefore it is not always possible to implement it. According to the results mentioned above, seeking to satisfy minimal norms required in building regulations, the quantity of windows should be increased up to several times. One or two additional windows could fit into the overall composition of the building. Nevertheless, in case of more windows, facades may seem unusually and, certainly, not typical of the vernacular building. From an aesthetic point of view, this might not be a good solution.

Using new glass structures for building facades is also possible. Foreign experience (United Kingdom, Ireland, Norway, etc.) shows that old traditions can be well extended referring to new contemporary architecture, maintaining a country-specific style, taking over a number of characteristic features and the rest adapting for today's needs and standards as well as making modernisation. Even in the protected areas, it is possible to use the latest architectural solutions (New Forest National Park Local Development Framework 2011). The usage of new modern solutions commits a message to the future generations about the age/time technologies, aesthetical norms, etc. of this period.

Also, a window is an important architectural element when talking about thermal characteristics of the building. The window has an impact on the efficiency of house energy. Glass structures, such as windows with a large glazed surface area at the south facade (direct gain windows), attached sunspaces, atriums and other modern solutions help with making energy savings in the passive way (Chwieduk 2004; Sadineni et al. 2011; Su 2011).

\section{Evaluation of a rational solution analysing daylighting in the reconstructed vernacular building and the problem of tradition continuity}

\subsection{MCDM methods applied for ranking alternative solutions}

The methods evaluate decision matrix $X$, which refers to $n$ alternatives that are evaluated in terms of $m$ criteria. Suppose, there is the initial decision-making matrix:

$$
X=\left(\begin{array}{cccc}
x_{11} & x_{12} & \ldots & x_{1 n} \\
x_{21} & x_{22} & \ldots & x_{2 n} \\
\vdots & \vdots & \vdots & \vdots \\
x_{m 1} & x_{m 2} & \cdots & x_{m n}
\end{array}\right),
$$

where $m$ is the number of criteria and $n$ is the number of alternatives. Member $x_{i j}$ denotes the performance measure of the $j$-th alternative in terms of the $i$-th criterion, $i=1$, $\ldots, m ; j=1, \ldots, n$.

The relative significances (or weights) of criteria are calculated applying the AHP method. Then, the weighted normalized decision-making matrices are formed, the relative significance of alternatives is calculated applying COPRAS, TOPSIS and WASPAS methods, the ranking order of alternative solutions is established and the utility degree of every alternative is calculated and compared.

\subsubsection{Complex Proportional Assessment (COPRAS)}

The method is presented with reference to Zavadskas and Kaklauskas (1996) and Antucheviciene et al. $(2011,2012)$.

To eliminate the units of criterion functions, the method under discussion uses the following equation:

$$
\bar{x}_{i j}=\frac{x_{i j}}{\sum_{j=1}^{n} x_{i j}},
$$


where $\bar{x}_{i j}$ is the normalized weighted value of each criterion, $i=1, \ldots, m ; j=1, \ldots, n$.

The weighted normalized value $\hat{x}_{i j}$ is calculated as:

$$
\hat{x}_{i j}=w_{i} \bar{x}_{i j} \text {, }
$$

where $w_{i}$ is the weight of the $i$-th criterion. In this particular case, it can be determined by applying the AHP, as described hereafter in Section 2.1.4.

The normalized weighted value of each $i$-th criterion belongs to benefit criteria or cost/loss criteria. Accordingly, the $j$-th alternative is then described by maximizing indices $\hat{x}_{i j}^{+}, i=1, \ldots, m$, where $i$ is associated with benefit criteria, and minimizing indices $\hat{x}_{i j}^{-}, i=1, \ldots, m$, where $i$ is associated with cost/loss criteria.

The sums of weighted normalized maximizing and minimizing indices $S_{j}^{+}$and $S_{j}^{-}$, respectively, are calculated as follows:

$$
S_{j}^{+}=\sum_{i=1}^{m} \hat{x}_{i j}^{+}, S_{j}^{-}=\sum_{i=1}^{m} \hat{x}_{i j}^{-} .
$$

Next, the relative significance $Q_{j}$ of each alternative is determined:

$$
Q_{j}=S_{j}^{+}+\frac{S_{\min } \sum_{j=1}^{n} S_{j}^{-}}{S_{j}^{-} \sum_{j=1}^{n} \frac{S_{\min }}{S_{j}^{-}}},
$$

where $S_{\min }=\min _{j} S_{j}^{-}, j=1, \ldots, n$.

The priorities of alternatives are defined according to the preference order of $Q_{j}$.

Utility degree $N_{j}$ is calculated:

$$
N_{j}=\frac{Q_{j}}{Q_{\max }} 100 \%,
$$

where $Q_{\min }=\max _{j} Q_{j}, j=1, \ldots, n$.

\subsubsection{Technique for Order Preference by Similarity to Ideal Solution (TOPSIS)}

The method is presented with reference to Hwang and Yoon (1981), Triantaphyllou (2000) and Antucheviciene et al. (2011, 2012).

TOPSIS uses vector normalization:

$$
\bar{x}_{i j}=\frac{x_{i j}}{\sqrt{\sum_{j=1}^{n} x_{i j}^{2}}},
$$

where $\bar{x}_{i j}$ is the normalized value, $i=1, \ldots, m ; j=1, \ldots, n$.

The weighted normalized value $\hat{x}_{i j}$ is calculated according to Eqn (7).
Ideal and negative-ideal solutions denoted as $A^{+}$ and $A^{-}$respectively are defined as follows:

$$
\begin{aligned}
& A^{+}=\left\{\hat{x}_{1}^{+}, \hat{x}_{2}^{+}, \ldots, \hat{x}_{m}^{+}\right\} ; \\
& A^{-}=\left\{\hat{x}_{1}^{-}, \hat{x}_{2}^{-}, \ldots, \hat{x}_{m}^{-}\right\},
\end{aligned}
$$

where $\hat{x}_{i}^{+}=\max _{j} \hat{x}_{i j}, \hat{x}_{i}^{-}=\min _{j} \hat{x}_{i j}, i=1, \ldots, m ; j=1, \ldots, n$, if the $i$-th criterion represents benefit; $\hat{x}_{i}^{+}=\min _{j} \hat{x}_{i j}, \hat{x}_{i}^{-}=\max _{j} \hat{x}_{i j}, i=1, \ldots, m ; j=1, \ldots, n$, if the $i$-th criterion represents cost/loss.

The Euclidean distance method is then applied to measure the distances of each alternative from the ideal solution and negative-ideal solution:

$$
\begin{gathered}
S_{j}^{+}=\sqrt{\sum_{i=1}^{m}\left(\hat{x}_{i j}-\hat{x}_{i}^{+}\right)^{2}} ; \\
S_{j}^{-}=\sqrt{\sum_{i=1}^{m}\left(\hat{x}_{i j}-\hat{x}_{i}^{-}\right)^{2}},
\end{gathered}
$$

where $S_{j}^{+}$is the distance from the ideal solution and $S_{j}^{-}$ is the distance from the negative-ideal solution, $i=1, \ldots$, $m ; j=1, \ldots, n$.

The relative significance of each alternative $Q_{j}$ is defined as follows:

$$
Q_{j}=\frac{S_{j}^{-}}{S_{j}^{+}+S_{j}^{-}}, 0 \leq Q_{j} \leq 1, j=1, \ldots, n .
$$

The best alternative can be found according to the preference order of $Q_{j}$. Utility degree $N_{j}$ can be calculated applying Eqn (10).

\subsubsection{Weighted Aggregated Sum Product Assessment (WASPAS)}

The method was developed by Zavadskas et al. (2012) and applied for dealing with civil engineering problems by Zavadskas et al. (2013a, b).

The linear normalization of the initial criteria values $x_{i j}$ is applied, and dimensionless values $\bar{x}_{i j}$ are obtained:

$$
\bar{x}_{i j}=\frac{x_{i j}}{\max _{j} x_{i j}},
$$

if $\max _{j} x_{i j}$ value is preferable or:

$$
\bar{x}_{i j}=\frac{\min _{j} x_{i j}}{x_{i j}},
$$

if $\min _{i} x_{i j}$ value is preferable.

The relative significance of each alternative $Q_{j}$ is calculated applying the joint generalized criterion of the weighted aggregation of additive and multiplicative methods: 


$$
Q_{j}=\lambda_{j} \sum_{i=1}^{m} \bar{x}_{i j} w_{i}+\left(1-\lambda_{j}\right) \prod_{i=1}^{m}\left(\bar{x}_{i j}\right)^{w_{i}},
$$

where $\lambda_{j}$ is the weighted coefficient.

$$
\text { If } \sum_{i=1}^{m} \bar{x}_{i j} w_{i}=Q_{j}^{(1)} \text {, and } \prod_{i=1}^{m}\left(\bar{x}_{i j}\right)^{w_{i}}=Q_{j}^{(2)} \text {, then, the }
$$

optimal values of weighted coefficient $\lambda_{j}$ can be calculated when finding minimum dispersion $\sigma^{2}\left(Q_{j}\right)$ and to assure the maximal accuracy of measurement respectively. The extreme of the function can be found when the derivative of Eqn (19), in regard to $\lambda$, is equated to zero:

$$
\lambda_{j}=\frac{\sigma^{2}\left(Q_{j}^{(2)}\right)}{\sigma^{2}\left(Q_{j}^{(1)}\right)+\sigma^{2}\left(Q_{j}^{(2)}\right)} .
$$

Variances $\sigma^{2}\left(Q_{j}^{(1)}\right)$ and $\sigma^{2}\left(Q_{j}^{(2)}\right)$ should be calculated as:

$$
\begin{gathered}
\sigma^{2}\left(Q_{j}^{(1)}\right)=\sum_{i=1}^{m} w_{i}^{2} \sigma^{2}\left(\bar{x}_{i j}\right) ; \\
\sigma^{2}\left(Q_{j}^{(2)}\right)=\sum_{i=1}^{m}\left(\frac{\prod_{i=1}^{m}\left(\bar{x}_{i j}\right)^{w_{i}} w_{i}}{\left(\bar{x}_{i j}\right)^{w_{i}}\left(\bar{x}_{i j}\right)^{\left(1-w_{i}\right)}}\right)^{2} \sigma^{2}\left(\bar{x}_{i j}\right) .
\end{gathered}
$$

In the case of a normal distribution of the initial data with credibility $q=0.05$, the estimates of the variances of the values of normalized criteria are calculated as follows:

$$
\sigma^{2}\left(\bar{x}_{i j}\right)=\left(0.05 \bar{x}_{i j}\right)^{2} .
$$

Alternatives can be ranked according to $Q_{j}$ (Eqn (19)). Utility degree $N_{j}$ can be calculated applying Eqn (10).

\subsubsection{Analytic Hierarchy Process (AHP)}

The AHP was introduced by Saaty (1980). This method is based on pairwise comparisons and can be helpful in determining importance (weight $w_{i}$ ) of each criterion.
The decision-maker has to express his opinion about the value of every single pairwise comparison of criteria in the linguistic form. Comparisons are quantified using a scale of a discrete set of numbers. In the current case, the intensity of importance is measured from 1 to 4 . According to this scale, the available values of pairwise comparisons are the members of the set: $\{4,3,2,1,1 / 2,1 / 3$, $1 / 4\}$. Then, the pairwise comparison matrix and eigenvector are derived. Next, the numbers are normalized and the weights of each criterion $w_{i}$ are specified.

One of the advantages of the AHP methodology is that it allows for slightly non-consistent pairwise comparisons. In the AHP, pairwise comparisons in a judgment matrix are considered to be adequately consistent if the corresponding Consistency Ratio (CR) is less than 10 percent (Saaty 1980). The CR is estimated using Random Consistency Index (RCI) and calculated Consistency Index (CI). RCI depends on the number of criteria $m$ (Triantaphyllou, Mann 1995). Consistency Index is calculated by the formula $\mathrm{CI}=\left(\lambda_{\max }-m\right) /(m-1)$ where $\lambda_{\max }$ is the approximated maximum eigenvalue. Then, the Consistency Ratio is estimated as CI/RCI.

\subsection{Alternatives and criteria for solving the problems of daylighting in the reconstructed vernacular building and tradition continuity}

For the case study, as an example, a vernacular dwelling from Aukštaitija region, Lithuania (Fig. 2) was chosen. There are three possible solutions (alternatives) to improving daylighting of the analysed vernacular building: $a_{1}-$ increasing the window size while maintaining typical traditional proportions (Fig. 3a); $a_{2}$ - increasing the quantity of windows (Fig. 3b); $a_{3}$ - using new glass structures for building facades (modern solution) (Fig. 3c).

The criteria are evaluated using quantitative $\left(x_{1}, x_{3}\right)$ and qualitative $\left(x_{2}, x_{4}, x_{5}, x_{6}\right)$ measures. Qualitative measures are evaluated using the five-level Likert item scale (Table 4). Quantitative measures use the results from research on window daylighting. However, it is noted, that the window glazed surface area is not equal to the whole window area like it was presumed in Section 1.2. Hence, window frames are considered when calculating the glazed surface area.

Criteria for a comparison of possible solutions are presented in Table 5.

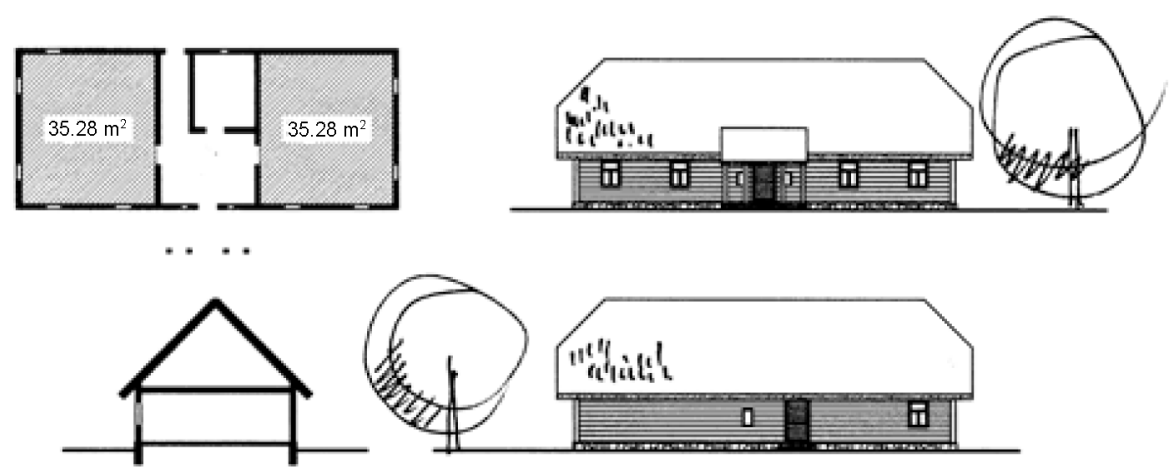

Fig. 2. The current situation (Šešelgis et al. 1965) 
a)
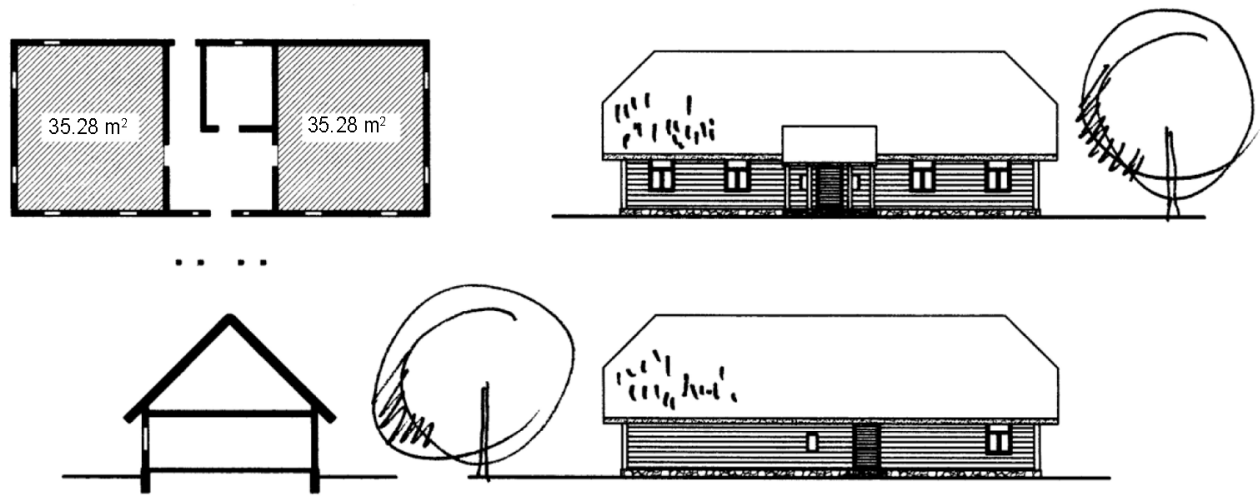

b)

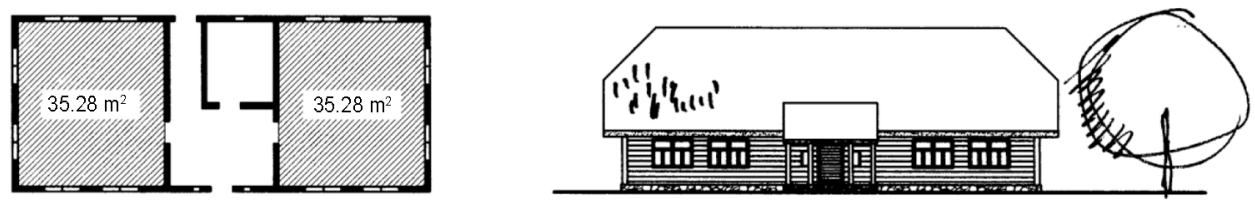

c)
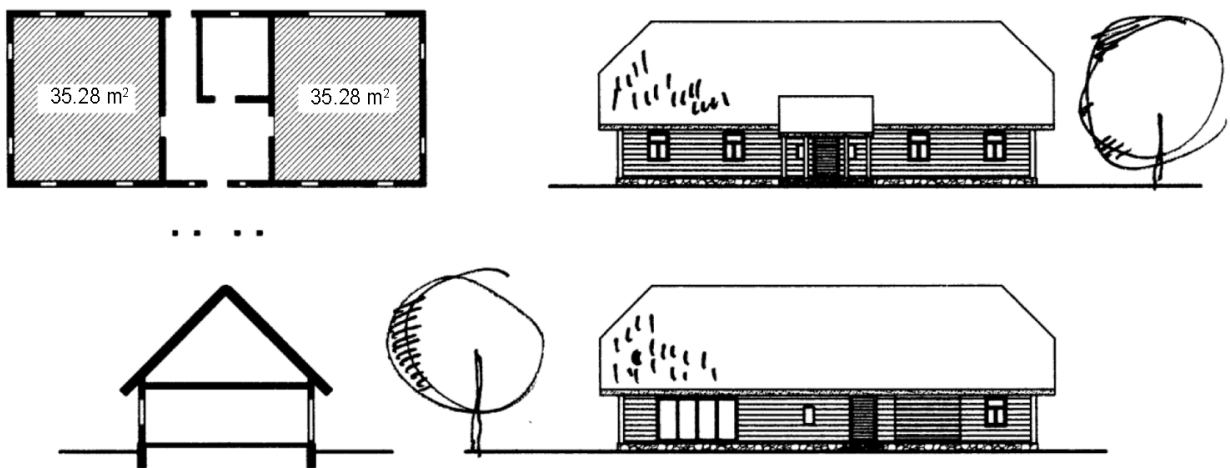

Fig. 3. Alternatives: a) increasing the window size; b) increasing the quantity of windows; c) using new glass structures (modern solution)

Table 4 . The scale evaluating qualitative criteria

\begin{tabular}{cll}
\hline \multirow{2}{*}{ Scale } & \multicolumn{2}{c}{ Criteria } \\
\cline { 2 - 3 } & \multicolumn{1}{c}{$x_{2}, x_{4}, x_{5}$} & \multicolumn{1}{c}{$x_{6}$} \\
\hline 1 & very weak & very unattractive \\
2 & weak & unattractive \\
3 & medium & medium \\
4 & strong & attractive \\
5 & very strong & very attractive \\
\hline
\end{tabular}

\subsection{Calculation results}

The weights of criteria $w_{j}$ are determined applying the AHP method (Table 6).

The Consistency Ratio coefficient is calculated as follows (for used methodology, see Section 2.1.4): 1) $\lambda_{\text {max }}=6.63$; 2) $C I=0.13$; 3) $R C I=1.24$; 4) $C R=0.10$.

As the Consistency Ratio does not exceed 10 percent, pairwise comparisons can be considered consistent. Consequently, the estimated weights of criteria can be used for future calculations when evaluating alternatives. 
Table 5. Criteria for comparing alternatives

\begin{tabular}{|c|c|c|c|c|c|c|}
\hline & \multirow[t]{2}{*}{ Criteria } & \multirow[t]{2}{*}{ Units } & \multirow[t]{2}{*}{ Optimum } & \multicolumn{3}{|c|}{$\begin{array}{l}\text { Alternatives for daylight- } \\
\text { ing problem solution }\end{array}$} \\
\hline & & & & $a_{1}$ & $a_{2}$ & $a_{3}$ \\
\hline$x_{1}-$ & $\begin{array}{l}\text { satisfying minimal daylighting regulations (according to } \\
\text { STR 2.02.01:2004): the ratio of the minimal required and } \\
\text { existing window glazed surface area }\end{array}$ & Times & $\min$ & 1.89 & 1.00 & 0.97 \\
\hline$x_{2}-$ & satisfying regulations on the building in protected areas & Points & $\max$ & 5 & 3 & 1 \\
\hline$x_{3}-$ & ratio of a part of the building facade and window glazed surface area & Times & $\max$ & 8.88 & 3.29 & 5.17 \\
\hline$x_{4-}$ & influence of a changed window on the whole building appearance & Points & $\min$ & 1 & 3 & 4 \\
\hline$x_{5-}$ & reflection of period/era norms, technologies, etc. & Points & $\max$ & 1 & 2 & 5 \\
\hline$x_{6}-$ & aesthetics & Points & $\max$ & 1 & 1 & 5 \\
\hline
\end{tabular}

Table 6. The weights of criteria $w_{j}$ applying the AHP method

\begin{tabular}{|c|c|c|c|c|c|c|c|}
\hline & \multicolumn{6}{|c|}{ Criteria } \\
\hline & & $x_{1}$ & $x_{2}$ & $x_{3}$ & $x_{4}$ & $x_{5}$ & $x_{6}$ \\
\hline \multirow{7}{*}{ 莺 } & $x_{1}$ & $1 / 1$ & $1 / 1$ & $4 / 1$ & $3 / 1$ & $3 / 1$ & $2 / 1$ \\
\hline & $x_{2}$ & $1 / 1$ & $1 / 1$ & $3 / 1$ & $4 / 1$ & $1 / 4$ & $1 / 1$ \\
\hline & $x_{3}$ & $1 / 4$ & $1 / 3$ & $1 / 1$ & $1 / 2$ & $1 / 3$ & $1 / 4$ \\
\hline & $x_{4}$ & $1 / 3$ & $1 / 4$ & $2 / 1$ & $1 / 1$ & $1 / 2$ & $1 / 4$ \\
\hline & $x_{5}$ & $1 / 3$ & $4 / 1$ & $3 / 1$ & $2 / 1$ & $1 / 1$ & $1 / 1$ \\
\hline & $x_{6}$ & $1 / 2$ & $1 / 1$ & $4 / 1$ & $4 / 1$ & $1 / 1$ & $1 / 1$ \\
\hline & $w_{j}$ & 0.287 & 0.175 & 0.050 & 0.070 & 0.233 & 0.186 \\
\hline
\end{tabular}

Ranking alternatives by applying COPRAS, TOPSIS and WASPAS methods (Eqns (5)-(23)) is presented in Tables 7-9.

According to calculation results applying COPRAS, TOPSIS and WASPAS methods, the alternatives are ranked as $a_{3} \succ a_{2} \succ a_{1}$.

Table 7. Ranking alternatives by applying the COPRAS method

\begin{tabular}{|c|c|c|c|c|c|c|c|}
\hline \multicolumn{8}{|c|}{ Normalised decision-making matrix } \\
\hline \multicolumn{2}{|c|}{ Criteria } & $\bar{x}_{1}$ & $\bar{x}_{2}$ & $\bar{x}_{3}$ & $\bar{x}_{4}$ & $\bar{x}_{5}$ & $\bar{x}_{6}$ \\
\hline \multirow{3}{*}{ 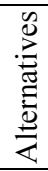 } & $a_{1}$ & 0.490 & 0.556 & 0.512 & 0.125 & 0.125 & 0.143 \\
\hline & $a_{2}$ & 0.259 & 0.333 & 0.190 & 0.375 & 0.250 & 0.143 \\
\hline & $a_{3}$ & 0.251 & 0.111 & 0.298 & 0.500 & 0.625 & 0.714 \\
\hline \multicolumn{8}{|c|}{ Normalised-weighted decision-making matrix } \\
\hline \multicolumn{2}{|c|}{ Criteria } & $\hat{x}_{1}$ & $\hat{x}_{2}$ & $\hat{x}_{3}$ & $\hat{x}_{4}$ & $\hat{x}_{5}$ & $\hat{x}_{6}$ \\
\hline \multirow{3}{*}{ 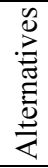 } & $a_{1}$ & 0.140 & 0.097 & 0.026 & 0.009 & 0.029 & 0.027 \\
\hline & $a_{2}$ & 0.074 & 0.058 & 0.010 & 0.026 & 0.058 & 0.027 \\
\hline & $a_{3}$ & 0.072 & 0.019 & 0.015 & 0.035 & 0.145 & 0.133 \\
\hline \multicolumn{8}{|c|}{ Results } \\
\hline & & \multirow{2}{*}{\multicolumn{2}{|c|}{$\begin{array}{c}\text { Maximizing } \\
\text { indices } \\
S_{j}^{+}\end{array}$}} & $\begin{array}{l}\text { Minimizing } \\
\text { indices }\end{array}$ & \multirow{2}{*}{\multicolumn{2}{|c|}{$\begin{array}{c}\text { Relative } \\
\text { significance } \\
Q_{j}\end{array}$}} & $\begin{array}{l}\text { Utility } \\
\text { degree }\end{array}$ \\
\hline & & & & $S_{j}^{-}$ & & & $N_{j}$ \\
\hline \multirow{3}{*}{ : } & $a_{1}$ & \multicolumn{2}{|c|}{0.179} & 0.149 & \multicolumn{2}{|c|}{0.270} & 61 \\
\hline & $a_{2}$ & \multicolumn{2}{|c|}{0.153} & 0.100 & \multicolumn{2}{|c|}{0.289} & 66 \\
\hline & $a_{3}$ & \multicolumn{2}{|c|}{0.313} & 0.107 & \multicolumn{2}{|c|}{0.441} & 100 \\
\hline
\end{tabular}

Table 8. Ranking alternatives applying the TOPSIS method

\begin{tabular}{|c|c|c|c|c|c|c|c|}
\hline \multicolumn{8}{|c|}{ Normalised decision-making matrix } \\
\hline \multicolumn{2}{|c|}{ Criteria } & $\bar{x}_{1}$ & $\bar{x}_{2}$ & $\bar{x}_{3}$ & $\bar{x}_{4}$ & $\bar{x}_{5}$ & $\bar{x}_{6}$ \\
\hline \multirow{3}{*}{ 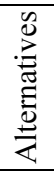 } & $a_{1}$ & 0.805 & 0.845 & 0.823 & 0.196 & 0.183 & 0.193 \\
\hline & $a_{2}$ & 0.426 & 0.507 & 0.305 & 0.588 & 0.365 & 0.193 \\
\hline & $a_{3}$ & 0.413 & 0.169 & 0.479 & 0.785 & 0.913 & 0.962 \\
\hline \multicolumn{8}{|c|}{ Normalised-weighted decision-making matrix } \\
\hline \multicolumn{2}{|c|}{ Criteria } & $\hat{x}_{1}$ & $\hat{x}_{2}$ & $\hat{x}_{3}$ & $\hat{x}_{4}$ & $\hat{x}_{5}$ & $\hat{x}_{6}$ \\
\hline \multirow{3}{*}{ 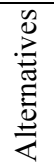 } & $a_{1}$ & 0.231 & 0.148 & 0.041 & 0.014 & 0.043 & 0.036 \\
\hline & $a_{2}$ & 0.122 & 0.089 & 0.015 & 0.041 & 0.085 & 0.036 \\
\hline & $a_{3}$ & 0.118 & 0.030 & 0.024 & 0.055 & 0.212 & 0.179 \\
\hline
\end{tabular}

Ideal and negative-ideal solutions

\begin{tabular}{|c|c|c|c|c|c|c|c|}
\hline \multicolumn{2}{|c|}{ Criteria } & $\hat{x}_{1}$ & $\hat{x}_{2}$ & $\hat{x}_{3}$ & $\hat{x}_{4}$ & $\hat{x}_{5}$ & $\hat{x}_{6}$ \\
\hline & $A^{+}$ & 0.118 & 0.148 & 0.041 & 0.014 & 0.212 & 0.179 \\
\hline & $A^{-}$ & 0.231 & 0.030 & 0.015 & 0.055 & 0.043 & 0.036 \\
\hline \multicolumn{8}{|c|}{ Results } \\
\hline & & $\begin{array}{c}\text { Distance } \\
\text { from } \\
\text { ideal } \\
\text { solution } \\
S_{j}^{+}\end{array}$ & \multicolumn{2}{|c|}{$\begin{array}{c}\text { Distance } \\
\text { from nega- } \\
\text { tive-ideal } \\
\text { solution } \\
S_{j}^{-}\end{array}$} & \multicolumn{2}{|c|}{$\begin{array}{c}\text { Relative } \\
\text { significance } \\
Q_{j}\end{array}$} & $\begin{array}{c}\text { Utility } \\
\text { degree } \\
N_{j}\end{array}$ \\
\hline \multirow{3}{*}{ 章 } & $a_{1}$ & 0.249 & \multicolumn{2}{|c|}{0.128} & \multicolumn{2}{|c|}{0.339} & 51 \\
\hline & $a_{2}$ & 0.204 & \multicolumn{2}{|c|}{0.132} & \multicolumn{2}{|c|}{0.392} & 59 \\
\hline & $a_{3}$ & 0.126 & \multicolumn{2}{|c|}{0.249} & \multicolumn{2}{|c|}{0.664} & 100 \\
\hline
\end{tabular}

In the case study, the best alternative is the third one (modern solution, namely using new glass structures for building facades), and the first alternative is ranked as the worst (increasing the window size while maintaining typical traditional proportions), whereas the suggestion to increase the quantity of windows takes the middle position.

The third alternative is an obvious leader when applying all MCDM methods used for the current research. Its degree of utility exceeds the second ranked alternative from 29 percent (according to the results of WASPAS) to 41 percent (according to the results of TOPSIS) while 
differences in the utility degree of the rest two alternative solutions are rather similar. Their differences are only 58 percent. Accordingly, the rationality of their implementation is almost equal. It is estimated that using the proposed new glass structures for building facades is the best compromise solution to satisfying daylighting demands and preserving the features of vernacular architecture in the above analysed case.

Table 9. Ranking alternatives applying the WASPAS method

\begin{tabular}{|c|c|c|c|c|c|c|c|}
\hline \multicolumn{8}{|c|}{ Normalised decision-making matrix } \\
\hline \multicolumn{2}{|c|}{ Criteria } & $\bar{x}_{1}$ & $\bar{x}_{2}$ & $\bar{x}_{3}$ & $\bar{x}_{4}$ & $\bar{x}_{5}$ & $\bar{x}_{6}$ \\
\hline \multirow{3}{*}{ 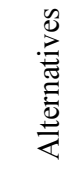 } & $a_{1}$ & 0.513 & 1.000 & 1.000 & 1.000 & 0.200 & 0.200 \\
\hline & $a_{2}$ & 0.970 & 0.600 & 0.371 & 0.333 & 0.400 & 0.200 \\
\hline & $a_{3}$ & 1.000 & 0.200 & 0.582 & 0.250 & 1.000 & 1.000 \\
\hline \multicolumn{8}{|c|}{ Normalised-weighted decision-making matrix for $Q_{j}^{(1)}$} \\
\hline \multicolumn{2}{|c|}{ Criteria } & $\hat{x}_{1}$ & $\hat{x}_{2}$ & $\hat{x}_{3}$ & $\hat{x}_{4}$ & $\hat{x}_{5}$ & $\hat{x}_{6}$ \\
\hline \multirow{3}{*}{ 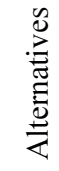 } & $a_{1}$ & 0.147 & 0.175 & 0.050 & 0.070 & 0.047 & 0.037 \\
\hline & $a_{2}$ & 0.278 & 0.105 & 0.019 & 0.023 & 0.093 & 0.037 \\
\hline & $a_{3}$ & 0.287 & 0.035 & 0.029 & 0.017 & 0.233 & 0.186 \\
\hline \multicolumn{8}{|c|}{ Normalised-weighted decision-making matrix for $Q_{j}^{(2)}$} \\
\hline \multicolumn{2}{|c|}{ Criteria } & $\hat{x}_{1}$ & $\hat{x}_{2}$ & $\hat{x}_{3}$ & $\hat{x}_{4}$ & $\hat{x}_{5}$ & $\hat{x}_{6}$ \\
\hline \multirow{3}{*}{$\frac{\mathscr{D}}{\underbrace{ \pm}_{0}}$} & $a_{1}$ & 0.826 & 1.000 & 1.000 & 1.000 & 0.6876 & 0.741 \\
\hline & $a_{2}$ & 0.991 & 0.915 & 0.951 & 0.927 & 0.8080 & 0.741 \\
\hline & $a_{3}$ & 1.000 & 0.755 & 0.973 & 0.908 & 1.0000 & 1.000 \\
\hline \multicolumn{8}{|c|}{ Results } \\
\hline & & \multicolumn{2}{|c|}{$\begin{array}{c}\text { Optimal } \\
\lambda_{j}\end{array}$} & \multicolumn{2}{|c|}{$\begin{array}{c}\text { Relative } \\
\text { significance } \\
Q_{j}\end{array}$} & \multicolumn{2}{|c|}{$\begin{array}{c}\text { Utility } \\
\text { degree } \\
N_{j}\end{array}$} \\
\hline \multirow{3}{*}{ 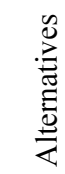 } & $a_{1}$ & \multicolumn{2}{|c|}{0.434} & \multicolumn{2}{|c|}{0.428} & \multicolumn{2}{|c|}{65} \\
\hline & $a_{2}$ & \multicolumn{2}{|c|}{0.410} & \multicolumn{2}{|c|}{0.472} & \multicolumn{2}{|c|}{71} \\
\hline & $a_{3}$ & \multicolumn{2}{|c|}{0.423} & \multicolumn{2}{|c|}{0.662} & \multicolumn{2}{|c|}{100} \\
\hline
\end{tabular}

\section{Conclusions}

The multiple criteria approach was proposed for analysing one of the problems of vernacular architecture, namely daylighting, and looking for the balance between norms for a contemporary building and tradition continuity. The problem was evaluated using multiple quantitative and qualitative measurements.

It was proposed to determine the relative significances of criteria applying the Analytic Hierarchy Process (AHP) and to find a rational solution to the problem using Complex Proportional Assessment (COPRAS), Technique for Order Preference by Similarity to Ideal Solution (TOPSIS) and Weighted Aggregated Sum Product Assessment (WASPAS).
The presented case study on indoor daylighting in Lithuanian vernacular architecture shows that the rational solution to improving daylighting in a reconstructed building and saving traditional features of vernacular architecture could be used in new glass structures, such as large glazed surface area windows, especially in the South facade of the building, that can be visible or partially hidden, e.g. recessed and sub-divided.

The other alternatives, such as increasing the size or quantity of windows, are almost similar (differ about 5-8 percent) and fall behind from the rational solution from 29 to 41 percent.

The same methods might be adopted for solving other vernacular architecture problems associated with the compatibility possibilities of tradition continuity and norms for a contemporary building.

\section{References}

Akadiri, P. O.; Olomolaiye, P. O.; Chinyio, E. A. 2013. Multicriteria evaluation model for the selection of sustainable materials for building projects, Automation in Construction 30: 113-125. http://dx.doi.org/10.1016/j.autcon.2012.10.004

Andriušyte, A.; Baltrušaitis, V.; Burinskaite, I.; Žumbakienè, G. 2008. Vernacular architecture of Dzūkija region. Vilnius: Petro ofsetas. 104 p. (in Lithuanian).

Antucheviciene, J.; Zakarevicius, A.; Zavadskas, E. K. 2011. Measuring congruence of ranking results applying particular MCDM methods, Informatica 22(3): 319-338.

Antucheviciene, J.; Zavadskas, E. K.; Zakarevicius, A. 2012. Ranking redevelopment decisions of derelict buildings and analysis of ranking results, Journal of Economic Computation and Economic Cybernetics Studies and Research 46(2): 37-62.

Battaini-Dragoni, G. 2008. The rural vernacular habitat, a heritage in our landscape, Futuropa: for a new vision of landscape and territory 1:3 [online], [cited 10 January 2012]. Available from Internet: http://www.unimi.it/img/news/Futuropa_1_EN.pdf.

Bertašiūte, R.; Baltrušaitis, V.; Burinskaite, I.; Žumbakienè, G. 2008. Vernacular architecture of West Aukštaitija region. Vilnius: Petro ofsetas. 96 p. (in Lithuanian).

Bertašiūtè, R.; Vasiliauskaitè, V.; Žumbakienè, G.; Bortkūnas, R.; Norvaišaite, N. 2009. Vernacular architecture of East Aukštaitija region. Vilnius: Petro ofsetas. 120 p. (in Lithuanian).

Bučas, J.; Mlinkauskienè, A. 2011. Evaluation of inhabitants' attitude to architecture in protected areas, Annual: Native Land [online], [cited 12 April 2012], 29-34 (in Lithuanian). Available from Internet: http://www.ziemgala.lt/saugykla/pdf/5_bucas.pdf.

Chwieduk, D. 2004. Solar energy utilisation, Opto-Electronics Review 12(1): 13-20.

Dubičiai. 1989. Vilnius: Mintis. 319 p. (in Lithuanian).

Foruzanmehr, A.; Vellinga, M. 2011. Vernacular architecture: questions of comfort and practicability, Building Research \& Information 39(3): 274-275.

http://dx.doi.org/10.1080/09613218.2011.562368

Hashemkhani Zolfani, S.; Zavadskas, E. K. 2013. Sustainable development of rural areas' building structures based on local climate, Procedia Engineering 57: 1295-1301. http://dx.doi.org/10.1016/j.proeng.2013.04.163 
Hwang, C. L.; Yoon, K. 1981. Multiple attribute decision making: methods and applications. A State-of-the-art Survey, Lecture Notes in Economics and Mathematical Systems, Berlin: Springer-Verlag. Vol. 186: $257 \mathrm{p}$. http://dx.doi.org/10.1007/978-3-642-48318-9

Jeong, J. S.; Garcia-Moruno, L.; Hernandez-Blanco, J. 2012. Integrating buildings into a rural landscape using a multicriteria spatial decision analysis in GIS-enabled web environment, Biosystems Engineering 112(2): 82-92. http://dx.doi.org/10.1016/j.biosystemseng.2012.03.002

Jeong, J. S.; Garcia-Moruno, L.; Hernandez-Blanco, J. 2013. A site planning approach for rural buildings into a landscape using a spatial multi-criteria decision analysis methodology, Land Use Policy 32: 108-118.

http://dx.doi.org/10.1016/j.landusepol.2012.09.018

Kačinskaite, I.; Baltrušaitis, V.; Burinskaite, I.; Žumbakienė, G. 2008. Vernacular architecture of Suvalkija (Süduva) region. Vilnius: Petro ofsetas. 96 p. (in Lithuanian).

Keizikas, A.; Andriušyte, A.; Šiožinytè, E. 2012. Research of some aspects of relation between ecology and energy efficiency in traditional architecture, Evolution of Science and Technology 4(1): 47-61 (in Lithuanian). http://dx.doi.org/10.3846/est2011.04

Kuzman, M. K.; Grošelj, P.; Ayrilmis, N.; ZbašnikSenegačnik, M. 2013. Comparison of passive house construction types using analytic hierarchy process, Energy and Buildings 64: 258-263.

http://dx.doi.org/10.1016/j.enbuild.2013.05.020

Macdonald, S. 2011. Contemporary architecture in historic urban environments [online], [cited 20 December 2012]. Available from Internet: http:/www.getty.edu/ conservation/publications_resources/newsletters/26_2/con temporary.html.

Mela, K.; Tiainen, T.; Heinisuo, M. 2012. Comparative study of multiple criteria decision making methods for building design, Advanced Engineering Informatics 26(4): 716726. http://dx.doi.org/10.1016/j.aei.2012.03.001

New Forest National Park Local Development Framework. 2011. Design guide. Supplementary planning document. London, UK. 79 p.

Ogunkah, I.; Yang, J. 2012. Investigating factors affecting material selection: the impacts on green vernacular building materials in the design-decision making process, Buildings 2(1): 1-32. http://dx.doi.org/10.3390/buildings2010001

Oram, R.; Stelfox, D. 2004. Traditional buildings in Ireland. Belfast: Impro Printing. $112 \mathrm{p}$.

Reglamentation of protection of Aukštaitija region National Park. Republic of Lithuania, 2002 (in Lithuanian).

Saaty, T. L. 1980. The Analytic Hierarchy Process: planning, priority setting, resource allocation. McGraw-Hill, USA. 287 p.

Sadineni, S. B.; Madala, S.; Boehm, R. F. 2011. Passive building energy savings: a review of building envelope components, Renewable and Sustainable Energy Reviews 15(8): 3617-3631. http://dx.doi.org/10.1016/j.rser.2011.07.014

STR 2.02.01:2004 Technical Construction Regulation "Residential Buildings". Republic of Lithuania, 2004 (in Lithuanian).
$\mathrm{Su}$, B. 2011. The impact of passive design factors on house energy efficiency, Architectural Science Review 54(4): 270-276. http://dx.doi.org/10.1080/00038628.2011.613638

Šaparauskas, J.; Zavadskas, E. K.; Turskis, Z. 2011. Selection of facade's alternatives of commercial and public buildings based on multiple criteria, International Journal of Strategic Property Management 15(2): 189-203. http://dx.doi.org/10.3846/1648715X.2011.586532

Šešelgis, K.; Baršauskas, J.; Čerbulènas, K.; Kleinas, M. 1965. Vernacular architecture of Lithuania: rural places and buildings. Vilnius: Mintis. Vol. 1: 151 p. (in Lithuanian).

Tamošaitiene, J.; Šipalis, J.; Banaitis, A.; Gaudutis, E. 2013. Complex model for the assessment of the location of high-rise buildings in the city urban structure, International Journal of Strategic Property Management 17(1): 93-109. http://dx.doi.org/10.3846/1648715X.2013.781968

Triantaphyllou, E. 2000. Multi-criteria decision making methods: a comparative study. Dordrecht: Kluwer Academic Publishers. 320 p. http://dx.doi.org/10.1007/978-1-4757-3157-6

Triantaphyllou, E.; Mann, S. H. 1995. Using the Analytic Hierarchy Process for decision making in engineering applications: some challenges, International Journal of Industrial Engineering: Applications and Practice 2(1): 35-44.

Yüksek, I.; Esin, T. 2013. Analysis of traditional rural houses in Turkey in terms of energy efficiency, International Journal of Sustainable Energy. http://dx.doi.org/10.1080/14786451.2013.769989

van Hoof, J.; van Dijken, F. 2008. The historical turf farms of Iceland: architecture, building technology and the indoor environment, Building and Environment 43(6): 10231030. http://dx.doi.org/10.1016/j.buildenv.2007.03.004

Zavadskas, E. K.; Antucheviciene, J. 2007. Multiple criteria evaluation of rural building's regeneration alternatives, Building and Environment 42(1): 436-451. http://dx.doi.org/10.1016/j.buildenv.2005.08.001

Zavadskas, E. K.; Antucheviciene, J.; Šaparauskas, J.; Turskis, Z. 2013a. Multi-criteria assessment of facades' alternatives: peculiarities of ranking methodology, Procedia Engineering 57: 107-112. http://dx.doi.org/10.1016/j.proeng.2013.04.016

Zavadskas, E. K.; Antucheviciene, J.; Šaparauskas, J.; Turskis, Z. 2013b. MCDM methods WASPAS and MULTIMOORA: verification of robustness of methods when assessing alternative solutions, Journal of Economic Computation and Economic Cybernetics Studies and Research 47(2): 5-20.

Zavadskas, E. K.; Kaklauskas, A. 1996. Multiple criteria evaluation of buildings. Vilnius: Technika. 275 p. (in Lithuanian).

Zavadskas, E. K.; Turskis, Z.; Antucheviciene, J.; Zakarevicius, A. 2012. Optimization of weighted aggregated sum product assessment, Electronics and Electrical Engineering 122(6): 3-6. http://dx.doi.org/10.5755/j01.eee.122.6.1810

Eglè ŠIOŽINYTE். PhD student at the Department of Architectural Engineering formerly and at the Department of Construction Technology and Management at present, Vilnius Gediminas Technical University, Lithuania. Research interests: development of vernacular architecture.

Jurgita ANTUCHEVIČIENÉ. Doctor, Assoc. Professor at the Department of Construction Technology and Management, Vilnius Gediminas Technical University, Lithuania. Research interests: sustainable development, construction business management and investment, multiple criteria analysis, decision-making theories and decision support systems. 